IRA-International Journal of Management \& Social Sciences

ISSN 2455-2267; Vol.05, Issue 02 (2016)

Pg. no. 227-244

Institute of Research Advances

http://research-advances.org/index.php/RAJMSS

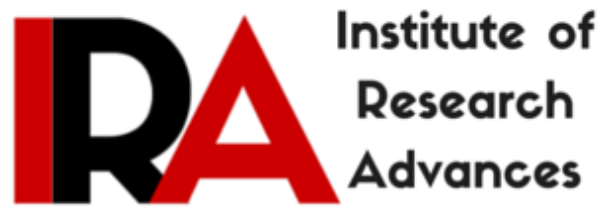

\title{
ABCD Analysis of On-line Campus Placement Model
}

\author{
${ }^{1}$ Varun Shenoy $\&{ }^{2}$ P. S. Aithal \\ ${ }^{1,2}$ Srinivas Institute of Management Studies, Pandeshwar, \\ Mangalore - 575 001, India.
}

Type of Review: Peer Reviewed.

DOI: http://dx.doi.org/10.21013/jmss.v5.n2.p3

\section{How to cite this paper:}

Aithal, S., \& Shenoy, V. (2016). ABCD Analysis of On-line Campus Placement Model. IRA-International Journal of Management \& Social Sciences (ISSN 24552267), 5(2), 227-244. doi:http://dx.doi.org/10.21013/jmss.v5.n2.p3

(C) Institute of Research Advances

\section{(oc) EY-NC}

This work is licensed under a Creative Commons Attribution-Non Commercial 4.0 International License subject to proper citation to the publication source of the work.

Disclaimer: The scholarly papers as reviewed and published by the Institute of Research Advances (IRA) are the views and opinions of their respective authors and are not the views or opinions of the IRA. The IRA disclaims of any harm or loss caused due to the published content to any party. 


\section{ABSTRACT}

The Present digital and technological era has facilitated the college campus recruitment process towards a manifestation of a vibrant shift in new systems of workforce engagements. The processes like gathering and compilation of information, filing of records, and all data related administrative work are done electronically, and therefore, paperwork is considerably diminished in the new model. Significantly, very less physical campus space is utilized for interview processes, and overall, consumes minimal time as compared with more traditional recruiting methods. Therefore, a brief study is undertaken in this research to discover the practical viability, usefulness, resourcefulness and universal applicability of online campus placement model to Recruiters, Students, Parents, Society, and Institutions. A new model of framework analysis named ABCD analysis developed by Aithal P. S. et. al. (2015) is adopted here for arriving at appropriate theory, hypothesis or postulate constructs regarding the ubiquitous appeal of the on-line campus placements. The determinant issues are identified and affecting factors under the constructs advantages, benefits, constraints, and disadvantages are determined under common key attributes. 158 Critical Constituent Elements (CCE) for are identified based on this analysis framework.

Keywords: Online Campus Placement, ABCD framework, Model Factor analysis, Model elemental analysis.

\section{Introduction}

The online oriented campus placement model at present is the application of electronic methods for registration and conduct of the interview process. The entire recruitment process is executed totally through websites, links, social media, emails, smart phones, and blogs and video conferencing applications over the Internet. Basically, this is a paper free green bottom up approach, where student Job aspirants based on their academic studies about various business models in course semesters, are motivated in the campus on their own to upload CV/Resumes in company portals on-line. Here, job descriptions and company profiles along with specified industry issues are also displayed requiring feasible solutions. Therefore, job aspiring students in campus are needed to work on such real business issues and perhaps prepare a solution synopsis either by case, report or whichever format specified by recruiting company for being evaluated on their problem-solving capacities. Here again, recruiter shortlists such uploaded resumes and applications through their online screening methodologies and intimate the shortlisted student through email or call or chat. Later, further rounds are completed through telephonic interviews and video conferencing. Those Students who are capable of practical problem solving and display capacity of organizational development are offered; where appointment letter is emailed as a document. Well as we know today, that present generation of job applicants including fresh student job seekers prefer any selection methodologies by companies who provide business related simulations, practice tests, training materials, demo plus positive evaluations backed by high validated material contents applying for jobs on-line [1-4]. Whilst various popular techniques are used to analyse strategic frameworks and models like Balanced Score card [5], SWOC and SWOT Analysis [6], Porter's Five Forces Model [7], Competitive Profile Matrix (CPM) analysis [8], EFE \& IFE Matrices [9], BCG analysing frameworks [10], PESTLE Analysis [11-12], and recently introduced ABCD framework [13], a research necessity was also born in analysing the future of campus placements in present digital world i.e. Online Mode of servicing students for attaining their jobs. As a matter of experimental, practical and futuristic approach, we have implemented the recently discovered and rapidly emerging new ABCD Framework of Model Analysis of Online Placement Model for arriving at key elements that reflects the possible inevitability of its existence in near future. 
IRA-International Journal of Management \& Social Sciences

\section{About ABCD Framework}

ABCD Framework is a technique to study various business models and research their effectiveness in stakeholders' value provision and ensure sustainable profitability through forecasted revenue generations. ABCD stands A for Advantages, B for Benefits, and C for Constraints and D for Disadvantages. The technique developed by Aithal et. al. (2015) [13] whose application results in an organized analysis of operational advantages, benefits, constraints, and disadvantages in a structured matrix format. The entire analysis is then segregated under various issues/focus areas and various operational factors affecting the function. The concept can be studied and analysed under each item by identifying their critical elements. This analysing technique being very simple gives very effective guidelines to identify and analyse the relevance and productiveness of any business models and new concepts developed. In the qualitative analysis using $\mathrm{ABCD}$ framework, the concept, system, strategy, technology, model and idea is further analysed by identifying constitutional critical factors. In the quantitative analysis using $A B C D$ framework, the appropriate score weightage is given to each constituent critical factor under each construct, through empirical research, the total score is calculated for each construct and by evaluating the scores, the concept, idea, system, technology, strategy can be accepted or rejected. Thus, ABCD analysis framework can be used as a research tool in these areas and is a simple but systematic analysing technique for business models, systems, concepts, ideas, technology, and strategy analysis.

\section{Literature Review on Analysis using ABCD Framework}

Recently, Aithal P. S. et. al. [13] constructed ABCD Model of Analysis to study any business model/strategy/concept/system and to examine its effectiveness in providing value for its stakeholders and sustainable profit through expected revenue generation. Application of ABCD analysis results in a structured list of business advantages, benefits, constraints, and disadvantages in a comprehensively coherent systematic matrix. The entire framework is segregated into various issues/area of focus and various business deployment factors affecting the business/concept which can be recognized and studied under each issue by identifying the appropriate critical effective element. This analyzing technique being simple gives the procedure to identify and analyze the effectiveness of any business model, business strategy, business concept/idea, and business system. The framework is used to analyze the features of "Working from Home" e-business model [14]. In this research, based on various factors which decide the Working from Home system, a model of various factors and their constituent critical elements affecting under organizational objectives, employer perspectives, employees' viewpoints, customers/students approach, environmental/societal point of view and system requirements were derived from a qualitative data collection instrument namely focus group method. It was discovered that the criterions supporting advantages and benefits are more effective compared to constraints and disadvantages of this model, so that working from home model may become more popular from the perspective of employers and employees in the organization going forward. ABCD analysis framework is used for analyzing Black ocean strategy concept [15-16]. The various aspects \&their constituent critical factors affecting this concept adopted in some of the business organizations provided for quick relief from the problems which were identified for organizational point of view, administrative point of view, employee point of view, operational point of view, business point of view and external issues point of view are determined under the four constructs - advantages, benefits, constraints, and disadvantages.

ABCD analysis framework has also been used for studying a concept "Higher Education Stage Model". The features of the concept are appraised based on identifying and examining the advantages, benefits, constraints, and disadvantages. The outcome supported the rationale of using ABCD framework methodology in any concept/idea performance evaluation [17-18]. ABCD analysis framework is also used for studying National Assessment and Accreditation Council (NAAC) accreditation process on higher education institutions [19]. The various characteristics of the NAAC accreditation system is evaluated based on identifying and analyzing the advantages, benefits, constraints, and disadvantages of some of the 
chosen issues like institutional issues, Faculty performance issues, student development/progression issues, social/environmental/community engagement issues, Infrastructure and Learning resources, and Issues on Innovations Creativity and Best Practices. The affecting factors under these issues found out using focus group method and the constituent critical elements under each factor are identified. The result supported the rationale of applying ABCD Framework in any System/concept performance assessments. In another paper on "Study on ABCD Analysis Technique for Business Models, business strategies, Operating Concepts \& Business Systems", the author discussed the detailed ABCD framework for quantitative methods and explained how this model can be used for four specific instances namely Business model, Business strategy, Operational concept and Functional systems. Finally, ABCD analyzing framework is compared with other known analyzing techniques like Balanced Score card [5], SWOC and SWOT Analysis [6], Porter's Five Forces Model [7], Competitive Profile Matrix (CPM) analysis [8], EFE \& IFE Matrices [9], BCG analyzing frameworks [10], PESTLE Analysis [11-12]. Application of ABCD Analysis Framework on Private University System in India is another paper published using this framework in which for six determinant issues related to the functioning of a University has been chosen. These are Organizational aspects, Students Progression, Faculty development, Societal \&other stakeholders' issues, Leadership, Governance and Issues on Innovations and Best Practices. Four key issues were identified under each of these and critical constituent elements under these factors are worked out. Through this analysis, 192 critical constituent elements which satisfy the success of a private university were explored [20-21].

Further, paper on "Study of New National Institutional Ranking Framework (NIRF) System using ABCD Framework, is published in which the ranking process is assessed using four constructs Advantages, Benefits, Constraints, and Disadvantages, considering all determinant issues in pivotal areas through analysing the major issues and identifying the critical constituent elements and concluded that NIRF provides a robust ranking suitable for higher educational institutions and it takes care of many small and subtle aspects comparable to quality assessment criterion of National Assessment and Accreditation Council [22]. ABC model recently developed by Aithal P.S \& Suresh Kumar P.M. [23], focused on measuring annual research productivity of higher educational institutions. According to this model, an institution can calculate its annual research performance using its annual research output by taking into consideration the factors such as the number of articles published in referred journals, the number of books published, and the number of chapters in edited book or number of business cases published in Journals. Studying the implications of a system or model considering all determinants in key areas and analysing the key issues to identify the effective factors and its critical constituent element is the task of ABCD analysis framework [24].

The ABCD framework is also used for elemental and factor analysis of the usage of dye-doped polymer films for photonic applications. The various affecting criterions under the determinant issues like Material Issues, Application Issues, Commercialization Issues, Production/Service providers Issues, Customer Issues, and Environmental/Social Issues. The constituent critical elements of these factors are listed under the four constructs - advantages, benefits, constraints and disadvantages of the ABCD technique and tabulated. The analysis has brought about 204 critical constituent elements which satisfy the success of this analysis methodology [25].

\section{ABCD Listing of Online Placement Model}

The advantages, benefits, constraints, and disadvantages of Online Industry Oriented Campus (OIOC) Placement Model are listed below [26-31] : 


\subsection{Advantages:}

\section{(1)Advantages to Recruiters}

- Online interviews are trouble free as date/day arrangement of the interviews can be easily executed from the business office.

- High resource mobility advantage can be reaped by the recruiter for the company.

- Online arrangement ensures serene and conducive interview process since less labour oriented.

- Facilitates company name branded at college campus which inturn multiplies the company popularity.

\section{(2) Advantages to Students}

- Students can give interviews at their own individual personal space anytime/anywhere process based on their schedule.

- Student Profile branding at company portals is ensured which in turn will merit their professional visibility.

- Students are relieved from pandemonium or congestion on college campuses otherwise which we would see during in any mega job-fairs or events otherwise.

- Students can also constantly check back with company for any freelance, part-times, internships or projects available with recruiters at regular intervals without any hand holding help from faculties.

\section{(3) Advantages to Institutions}

- Trouble-free date/day arrangement of the interviews is facilitated for institutions as they update the portal by inputting the possible interview dates.

- Anytime/Anywhere access to the institution gives the flexibility in adjusting placement commitments against the academic ones.

- Electronic interview ensures serene and conducive interview process without much use of college staff in arranging infrastructure.

- Online placement arrangement facilitates college name branding at company portals for a worldwide appeal.

(4) Advantages to Parents

- On-line placement program assists professional parents to volunteer assistance for their children to also give interview from home.

- Anytime / anywhere interview initiation can relieve parents of anxiety to get to the venue and avoid panics.

- The proof of interview / selection can be easily and quickly shared with parents.

- The serene and calm environment of on-line interview motivates parents to motivate their children to give more interviews.

- On-line interview selection can be advertised or promoted by parents in the society about their children's selection which uplifts the social status of families.

(5) Advantages for Society

- Through online interview process, the society merits with better work-life balance for the candidates who are also citizens for better life expectancy.

- The Anytime/Anywhere schedule of online recruitment will lessen up congestion and reduce peak hour build-up at major streets and transport points.

- Socially responsible walk-in and pooled job drives can be easily monitored through on-line recruiting.

- On-line recruitment facilitates in realising Green Environmental objectives

- Through electronic placement events, Industry contributes to the digital growth in the society as their brand name becomes Household names which benefits families to realize employment dreams uplifting the economy. 


\subsection{Benefits :}

\section{(1) Benefits to Recruiters}

- Alignment of business requirements anytime anywhere to the campus interview process available for companies due to quick information sharing facilities at Portals.

- Online Interviews can be executed anytime/anywhere as well per business convenience.

- Online interviews set ups facilitate easy access and user friendly experience for overall recruitment administration.

- HR Dept. can easily evaluate the proceedings of interview even from their remote or offshore locations.

- Easy provision of resource for part-time, projects and internships can also be made by the businesses.

\section{(2) Benefits to Students}

- Easy alignment of practiced skills to apply on-line is possible for modern age generation at online interviews.

- Less laborious schedule will ease stress on student physique and intellect.

- Students can better know their employability acceptance progress by accessing online industry feedbacks at regular intervals.

- Student's individual profile is showcased on-line universally for better career opportunities.

\section{(3) Benefits to Institutions}

- Electronic recruitment process facilitates easy alignment of college requirements anytime anywhere in the interview process

- Student Mobilization is easy for the placement office.

- Online interview facilitates easy access and user friendly experience for institutions to track the performance of their student and interview conduct etc.

- College can easily monitor the interview proceedings

- Universal College Student branding for part-time, project and internship placements at professional circle online is also ensured.

\section{(4) Benefits to Parents}

- Parents can also get visual proofs through electronic media about their children's results when shared.

- Parents can take their own time to facilitate their children to go to interview without disturbing their daily affairs.

- The on-line nature of the interview facilitates relief on parents mind about physical well-being of their kids.

- Increased confidence among parents about the interview updates as they will be easy to provide by their student children.

- On-line interview selection can be advertised or promoted by parents in the society about their children in enhancing their social.

\section{(5) Benefits for Society}

- The flexible opportunity to give interview for candidates on-line facilitates in relaxed mind set for candidates while facing the rounds. This facilitates societal well-being.

- On-line recruitment facilitates in pollution control and better environment preservation.

- On-line interview process makes candidates tech-savvy ensuring all the citizens becoming technologically advanced in the society benefitting the nation.

- On-line recruitment also facilitates technological advancement of the civil society

- Advertisement for recruiter in the society as provider of digital employment ensuring Corporate Social Responsibility. 


\subsection{Constraints :}

(1) Constraints to Recruiters

- Lack of Motivation from managers to automate recruiting process with fear of losing manual jobs is a constraint in the implementation process of e-interviews.

- The sourcing avenues may not have the IT environment matching that of the recruiters to execute the process.

- High expenses and costs may be involved in managing the recruitment software and applications.

- Difficult to manually invigilate and oversee the interview proceedings.

- Possibilities of failure of on-line process due to various technical reasons are also evident.

(2) Constraints to Students

- Lack of invigilator or manual supervision may leave students confused while navigating online.

- Students tend to take the schedule light and easy as they believe they can access the process anytime anywhere.

- Inability of the student to access internet, applications and system may lead to their innocence and ignorance on job offer status.

- Students tend to become lethargic and lazy in absence of high pressure corporate environment.

- Student image failure when companies drop profiles of unqualified or rejected profiles from their portals.

\section{(3) Constraints to Institutions}

- Lack of motivation in students in participating further at automated recruiting process along with fear of interviews.

- The college may not match the timing of interview with that of the recruiter due to various university and academic constraints.

- High Power consumption may be involved in managing on-line interview which sometimes cause burden on college cost overheads.

- Absence of company personnel in monitoring the interview process at campus makes the event very casual.

- Event Failure may lead to heavy beating of future college image as a recruitment avenue.

(4) Constraints to Parents

- Parents cannot directly access their children's performance feedback directly in recruiter portals.

- Parents may not be able to gather all information regarding the interview if they are not techsavvy.

- A scheduled interview from home can cause inconvenience for parent household.

- Parents may have to deal with emotional stress of their kids due to exposure of technicalities involving in on-line process.

- Creation of inferiority complex among parents whose kids fail at interviews.

(5) Constraints for Society

- The flexibility in On-line recruitment process may lead to laziness and lethargy among the candidates leading to procrastinated society.

- The power usage for conduct of on-line recruitment can be enormous where society can be burdened by power-cut woes.

- Over-subscription to available positions on-line can cause websites to crash or slowdown.

- On-line recruitment may lead to technological slavery among the public.

- Unnecessary competition among families to force their kids to take up professions against their dreams. 
4.4 Disadvantages :

(1) Disadvantages to Recruiters

- Installation and implementation of process may become rigid and tedious as recruiter needs to configure and map the IT infrastructure services to that of the college.

- Invalidity of on-line process if the sourcing avenue does not have or support the required IT environment of the recruiter.

- Technical error and system lag can delay the entire recruitment process.

- The quality of manpower obtained post the process may not be satisfactory.

- Creation of negative image for recruiter if the e-recruitment process fails due t various technical and non-technical reasons.

(2) Disadvantages to Students

- Any confusion at any stage of on-line recruitment may lead to demotivation among students rendering the event ineffective.

- Student Absence as well not accessing the interview modules online can again render the process ineffective affecting student career.

- Rigidity and Procrastination may lead the student to lose control on administering himself at company on-line portals and thereby miss out job opportunities.

- On-line interview dependence may lead to total innocence and ignorance of physical interview process existence.

- Image failure will depress students at campus, if company rejects and removes their profile from company database.

(3) Disadvantages to Institutions

- Installation and implementation of process may become rigid and tedious.

- The academic schedule always conflicts with the recruiters' schedule.

- Technical error and system lag can delay the recruitment process.

- Any technical snag or application downtime in e-recruiting tools during the interview may cause restlessness among students which may possibly lead to disorder.

- Creation of negative image of college in event of failure of the on-line process due to unavoidable reasons.

(4) Disadvantages to Parents

- The flexible feature of the on-line interview process may not match with time flexibility of Parents.

- Parents who are not tech-savvy can be easily fooled by their children due to their lack of ability to understand the technicalities.

- Non-availability of internet or system at home can make the online-interview difficult to administer.

- The negative emotional distress of their kids due to on-line interview fallout if any will have to be suffered by the parents.

- Social Stigma on Parents whose kids either get rejected or is disqualified in on-line interview process.

(5) Disadvantages to Society

- Flexibility in on-line recruitment can make candidate expecting ease at all levels of tasks in life where his purpose of putting efforts get decreased.

- On-line interview schedule can cause over-crowding of network by job seekers during the scheduled time. In such cases, other users are deprived of convenience.

- On-line recruitment may fail if the number of candidates is above the limit that applications and portals can be access burdening the servers.

- On-line recruitment may cause manual job loss at recruiter side leading to unemployment in the economy. 
- Creation of social inequalities among families.

\section{ABCD Framework Applied to OIOC Placement Model}

As per the ABCD framework, the various determinant issues related to the success of On-line Campus Placement Model identified are (1) Recruiter Issues (2) Student Issues (3) College/Institutional Issues (4) Parental Issues and (5) Societal Issues.

(i) Recruiters Issues :

The affecting factors under key issues for On-line Placement Process like user friendliness, event atmosphere, Flexibility, Administration, and Branding are determined under the constructs of Advantages, Benefits, Constraints and Disadvantages of the System.

(2) Students Issues :

The affecting factors under key issues like Flexible schedule, user friendliness, event atmosphere, Administration, and Branding for Student Community are also determined under the constructs of Advantages, Benefits, Constraints and Disadvantages of the System.

(3) Institutional Issues :

Similarly, College or Institutional level issues are determined under the constructs Advantages, Benefits, Constraints and Disadvantages of the System involving like user friendliness, event atmosphere, Flexibility, Administration, and Branding.

(4) Parental Issues :

The affecting factors under key issues also for Parents and Guardians like their perspective of Event Atmosphere, Flexibility, User Friendliness, Administration, and Branding are determined under the constructs Advantages, Benefits, Constraints and Disadvantages of the System.

(5) Societal Issues:

Finally, the affecting factors for society under key issues like Event Atmosphere, Flexibility, User Friendliness, Administration, and Branding are determined under the constructs Advantages, Benefits, Constraints and Disadvantages of the System as per the analysing model.

The affecting factors under key attributes like User friendliness, Event Atmosphere, Flexibility, Administration, and Branding for each determinant issues are determined under the constructs Advantages, Benefits, Constraints and Disadvantages of the model are determined using focus group method [32-37] and are listed in Table 1.

Table1 : Issues and Factors of On-line Placement Model using ABCD framework

I. Determinant Issues identified for Recruiters

\begin{tabular}{|l|l|l|l|l|}
\hline Key Attribute & Advantage & Benefits & Constraints & Disadvantages \\
\hline Flexibility & Trouble-free & Easy alignment & $\begin{array}{l}\text { Lack of } \\
\text { motivation }\end{array}$ & $\begin{array}{l}\text { Rigid and Tedious } \\
\text { Installation and } \\
\text { implementation of } \\
\text { process }\end{array}$ \\
\hline Schedule & $\begin{array}{l}\text { Anytime / } \\
\text { Anywhere }\end{array}$ & $\begin{array}{l}\text { High Resource } \\
\text { Mobility }\end{array}$ & $\begin{array}{l}\text { IT } \\
\text { Environment } \\
\text { Mismatch }\end{array}$ & $\begin{array}{l}\text { Poor IT } \\
\text { Infrastructure } \\
\text { Support }\end{array}$ \\
\hline Administration & $\begin{array}{l}\text { Anytime / } \\
\text { Anywhere }\end{array}$ & $\begin{array}{l}\text { Easy access and } \\
\text { user-friendly }\end{array}$ & $\begin{array}{l}\text { High Expenses, } \\
\text { Overheads and } \\
\text { Costs }\end{array}$ & $\begin{array}{l}\text { Technical Error } \\
\text { and System Lag }\end{array}$ \\
\hline Atmosphere & $\begin{array}{l}\text { Serene and } \\
\text { Conducive }\end{array}$ & Less Laborious & $\begin{array}{l}\text { Manual } \\
\text { Supervision } \\
\text { Challenges }\end{array}$ & $\begin{array}{l}\text { Unsatisfactory } \\
\text { Quality }\end{array}$ \\
\hline Branding & Publicity & Marketing & Brand Misuse & Negative Imagery \\
\hline
\end{tabular}




\section{Determinant Issues identified for Students}

\begin{tabular}{|l|l|l|l|l|}
\hline Key Attribute & Advantages & Benefits & Constraints & Disadvantages \\
\hline Flexibility & $\begin{array}{l}\text { Individual } \\
\text { Personal } \\
\text { Space }\end{array}$ & $\begin{array}{l}\text { Practical Skill } \\
\text { Applications }\end{array}$ & $\begin{array}{l}\text { Navigation } \\
\text { Confusion }\end{array}$ & De-motivation \\
\hline Schedule & $\begin{array}{l}\text { Anytime / } \\
\text { Anywhere }\end{array}$ & $\begin{array}{l}\text { Less laborious } \\
\text { schedule }\end{array}$ & Casual Take & $\begin{array}{l}\text { Student Absence } \\
\text { \& Access Failure }\end{array}$ \\
\hline Administration & $\begin{array}{l}\text { Anytime / } \\
\text { Anywhere } \\
\text { Atmosphere }\end{array}$ & $\begin{array}{l}\text { Self-Evaluation } \\
\text { and Access }\end{array}$ & $\begin{array}{l}\text { Student } \\
\text { Innocence and } \\
\text { Ignorance }\end{array}$ & $\begin{array}{l}\text { Rigidity and } \\
\text { Procrastination }\end{array}$ \\
\hline Branding & $\begin{array}{l}\text { Student Profile } \\
\text { branding at } \\
\text { company } \\
\text { portals }\end{array}$ & $\begin{array}{l}\text { Universal profile } \\
\text { showcase on-line } \\
\text { Corporate } \\
\text { Environment }\end{array}$ & $\begin{array}{l}\text { Student Image } \\
\text { Failure }\end{array}$ & $\begin{array}{l}\text { Student Laziness } \\
\text { and Lethargy } \\
\text { Depression }\end{array}$ \\
\hline
\end{tabular}

\section{Determinant Issues identified for Colleges and Institutions}

\begin{tabular}{|l|l|l|l|l|}
\hline Key Attribute & Advantages & Benefits & Constraints & Disadvantages \\
\hline Flexibility & $\begin{array}{l}\text { Easy time/date } \\
\text { fixing }\end{array}$ & $\begin{array}{l}\text { Anytime student } \\
\text { to company } \\
\text { alignment }\end{array}$ & Demotivation & $\begin{array}{l}\text { Rigid and Tedious } \\
\text { Installation and } \\
\text { implementation of } \\
\text { process }\end{array}$ \\
\hline Schedule & $\begin{array}{l}\text { Anytime / } \\
\text { Anywhere }\end{array}$ & $\begin{array}{l}\text { Easy Student } \\
\text { Mobilization }\end{array}$ & $\begin{array}{l}\text { Timing } \\
\text { Mismatch }\end{array}$ & $\begin{array}{l}\text { Academic } \\
\text { Schedule conflict } \\
\text { with Recruiter }\end{array}$ \\
\hline Administration & $\begin{array}{l}\text { Anytime } \\
\text { Anywhere }\end{array}$ & $\begin{array}{l}\text { Easy access and } \\
\text { user-friendly }\end{array}$ & $\begin{array}{l}\text { High Power } \\
\text { consumption }\end{array}$ & $\begin{array}{l}\text { Technical Errors } \\
\text { and System Lags }\end{array}$ \\
\hline Atmosphere & $\begin{array}{l}\text { Serene and } \\
\text { Conducive }\end{array}$ & Easy Monitor & $\begin{array}{l}\text { Casual and } \\
\text { lack of campus } \\
\text { seriousness }\end{array}$ & $\begin{array}{l}\text { Restlessness and } \\
\text { Disorder }\end{array}$ \\
\hline Branding & $\begin{array}{l}\text { Robust } \\
\text { Publicity }\end{array}$ & $\begin{array}{l}\text { Student } \\
\text { Marketing }\end{array}$ & Image threat & Negative Imagery \\
\hline
\end{tabular}




\begin{tabular}{|c|c|c|c|c|}
\hline \multicolumn{5}{|c|}{ IV. Determinant Issues identified for Parents } \\
\hline Key Attribute & Advantages & Benefits & Constraints & Disadvantages \\
\hline Flexibility & $\begin{array}{l}\text { Parent } \\
\text { Volunteering }\end{array}$ & $\begin{array}{ll}\text { Avoids } & \text { Rush } \\
\text { Hours } & \end{array}$ & $\begin{array}{lr}\text { Lack r of } \\
\text { Interest and } \\
\text { Lethargy }\end{array}$ & $\begin{array}{l}\text { Non-flexible } \\
\text { Parental Schedule }\end{array}$ \\
\hline Schedule & Anxiety Relief & $\begin{array}{l}\text { Schedule } \\
\text { Matching }\end{array}$ & $\begin{array}{l}\text { Timing } \\
\text { Mismatch }\end{array}$ & $\begin{array}{l}\text { Comprehension } \\
\text { Inability }\end{array}$ \\
\hline Administration & Easy Proof & Good Control & $\begin{array}{l}\text { Inability to } \\
\text { understand the } \\
\text { technical } \\
\text { aspects }\end{array}$ & $\begin{array}{l}\text { Non-availability } \\
\text { of internet or } \\
\text { system }\end{array}$ \\
\hline Atmosphere & $\begin{array}{lr}\text { Serene r and } \\
\text { Calm Home } \\
\text { Environment }\end{array}$ & $\begin{array}{l}\text { Increased } \\
\text { confidence }\end{array}$ & $\begin{array}{l}\text { Emotional } \\
\text { Stress }\end{array}$ & $\begin{array}{l}\text { Mental Distress } \\
\text { and Suffering }\end{array}$ \\
\hline Branding & \begin{tabular}{|l|} 
Societal \\
Promotion
\end{tabular} & $\begin{array}{l}\text { Enhanced Social } \\
\text { Status }\end{array}$ & $\begin{array}{l}\text { Inferiority } \\
\text { Complex }\end{array}$ & Social Stigma \\
\hline \multicolumn{5}{|c|}{ V. Determinant Issues identified for Society } \\
\hline Key Attribute & Advantages & Benefits & Constraints & Disadvantages \\
\hline Flexibility & $\begin{array}{ll}\text { Better } & \text { Life } \\
\text { Balance } & \end{array}$ & \begin{tabular}{|ll} 
Societal & Well- \\
Being & \\
\end{tabular} & $\begin{array}{l}\text { Procrastinated } \\
\text { society }\end{array}$ & Lack of Initiative \\
\hline Schedule & \begin{tabular}{|l} 
Zero \\
Congestion
\end{tabular} & $\begin{array}{l}\text { Pollution Control } \\
\text { and Better } \\
\text { Environment } \\
\end{array}$ & \begin{tabular}{|ll} 
Burden & on \\
Resources &
\end{tabular} & $\begin{array}{l}\text { Depriving of E- } \\
\text { Convenience }\end{array}$ \\
\hline Administration & Easy Monitor & Digitization & Digital Chaos & $\begin{array}{ll}\text { Digital } & \text { Over } \\
\text { Crowding } & \end{array}$ \\
\hline Atmosphere & \begin{tabular}{|l} 
Green \\
Environment \\
objective \\
realization
\end{tabular} & $\begin{array}{l}\text { Civil Society } \\
\text { Technological } \\
\text { Advancement }\end{array}$ & \begin{tabular}{|l|} 
Public \\
Technological \\
Slavery
\end{tabular} & $\begin{array}{l}\text { Manual Job Loss } \\
\text { and } \\
\text { Unemployment }\end{array}$ \\
\hline Branding & $\begin{array}{l}\text { High } \\
\text { Stakeholder } \\
\text { Image }\end{array}$ & $\begin{array}{lr}\text { Media Press } \\
\text { Publicity for } \\
\text { Stakeholders }\end{array}$ & $\begin{array}{l}\text { Cut-throat } \\
\text { competition } \\
\text { among families }\end{array}$ & $\begin{array}{l}\text { Creation of social } \\
\text { inequalities } \\
\text { among families }\end{array}$ \\
\hline
\end{tabular}

\section{Critical Constituent Elements as per ABCD model}

The critical constituent elements of these factors affecting Campus Placement Model are listed under the four constructs - advantages, benefits, constraints and disadvantages of the ABCD technique and tabulated in tables 2 to 5 . 
Table 2: Advantages factors of On-line Campus Placement Model and their critical constituent elements

\begin{tabular}{|c|c|c|c|}
\hline $\begin{array}{l}\text { Sl. } \\
\text { No. }\end{array}$ & Issue & Factors affecting & Critical Constituent Elements \\
\hline \multirow{8}{*}{1} & \multirow{8}{*}{ Recruiters } & \multirow{2}{*}{ Trouble-free } & Interview Date/Day Arrangement \\
\hline & & & Easy Correspondence \\
\hline & & \multirow{2}{*}{ Anytime / Anywhere } & Schedule fixing \\
\hline & & & Schedule Amendments \\
\hline & & \multirow{2}{*}{ Serene and Conducive } & Execution Atmosphere \\
\hline & & & Smooth Communication \\
\hline & & \multirow[t]{2}{*}{ Publicity } & Widespread \\
\hline & & & Campus and Word of Mouth \\
\hline \multirow{6}{*}{2} & \multirow{6}{*}{ Students } & Individual Personal Space & To keep calm and composure \\
\hline & & \multirow{2}{*}{ Anytime/Anywhere } & Flexibility to attend \\
\hline & & & Mobility and adaptable \\
\hline & & $\begin{array}{l}\text { Student Profile branding at company } \\
\text { portals. }\end{array}$ & $\begin{array}{l}\text { Wide Online publicity and } \\
\text { recognition }\end{array}$ \\
\hline & & & Less Chaotic \\
\hline & & Serene and conducive atmosphere & Less Laborious \\
\hline \multirow{8}{*}{3} & \multirow{8}{*}{ Institutions } & \multirow{2}{*}{ Easy time/date fixing } & Online Booking \\
\hline & & & Online Schedule Amendments \\
\hline & & \multirow{2}{*}{ Anytime } & Adjustable Schedule \\
\hline & & & Matchable Time \\
\hline & & \multirow{2}{*}{ Anywhere } & Relaxed Venue Fixing \\
\hline & & & Mutual Venue Agreement \\
\hline & & \multirow{2}{*}{ Robust Publicity } & Online Branding \\
\hline & & & Company and Recruiter Branding \\
\hline \multirow{8}{*}{4} & \multirow{8}{*}{ Parents } & \multirow{2}{*}{ Parent Volunteering } & Easy Supervision \\
\hline & & & Controlled Monitoring \\
\hline & & \multirow{2}{*}{ Anxiety Relief } & No Rush Hour \\
\hline & & & Congestion Free \\
\hline & & Easy Proof & Available online \\
\hline & & Societal Promotion & For Social Status \\
\hline & & Serene and Calm Home Fnvironment & Relaxed Student liability \\
\hline & & serene and Calm Home Environment & Decreased Student Anxiety \\
\hline \multirow{8}{*}{5} & \multirow{8}{*}{ Society } & \multirow{2}{*}{ Better Life Balance } & Better Interview time management \\
\hline & & & Process Carry Forward \\
\hline & & \multirow{2}{*}{ Zero Congestion } & Work from Home \\
\hline & & & Interview from any point \\
\hline & & \multirow{2}{*}{ Green Environment objective realization } & Zero Noise Pollution \\
\hline & & & Zero Congestion \\
\hline & & \multirow{2}{*}{ High Stakeholder Image } & Societal Recognition \\
\hline & & & Social Status \\
\hline
\end{tabular}


Table 3 : Beneficial factors of On-line Campus Placement Model and their critical constituent elements

\begin{tabular}{|c|c|c|c|}
\hline $\begin{array}{l}\text { Sl. } \\
\text { No. }\end{array}$ & Issue & Factors affecting & $\begin{array}{l}\text { Critical Constituent } \\
\text { Elements }\end{array}$ \\
\hline \multirow[t]{8}{*}{1} & \multirow[t]{8}{*}{ Recruiters } & \multirow[t]{2}{*}{ High Resource Mobility } & Multiple Campus Benefit \\
\hline & & & High people pool \\
\hline & & \multirow{2}{*}{ Easy Alignment of requirements } & Anytime to the event \\
\hline & & & Anywhere to the process \\
\hline & & \multirow[t]{2}{*}{ Easy access and user-friendly } & Candidate Benefit \\
\hline & & & Job Seeker Satisfaction \\
\hline & & \multirow[t]{2}{*}{ Easy proceedings evaluation } & Office Convenience \\
\hline & & & Feedback Option \\
\hline \multirow[t]{8}{*}{2} & \multirow[t]{8}{*}{ Students } & \multirow[t]{2}{*}{ Easy alignment of skills } & Skill Mapping \\
\hline & & & Requirement Matching \\
\hline & & \multirow[t]{2}{*}{ Less Laborious schedule } & Login Credentials \\
\hline & & & Electronic Based \\
\hline & & \multirow{2}{*}{$\begin{array}{l}\text { Easy to understand the } \\
\text { employability acceptability } \\
\text { progress }\end{array}$} & Performance Mapping \\
\hline & & & Interview Feedback Review \\
\hline & & \multirow{2}{*}{$\begin{array}{l}\text { Universal branding of student } \\
\text { profile }\end{array}$} & Company Portal Access \\
\hline & & & Online Professional Presence \\
\hline \multirow[t]{8}{*}{3} & \multirow[t]{8}{*}{ Institutions } & \multirow{2}{*}{$\begin{array}{c}\text { Easy alignment of college } \\
\text { requirements }\end{array}$} & Talent Mapping \\
\hline & & & Skill set submission \\
\hline & & \multirow[t]{2}{*}{ Easy access and user-friendly } & Secured passkeys \\
\hline & & & Convenient Supervision \\
\hline & & \multirow[t]{2}{*}{ Easy Student Mobilization } & Registration Convenience \\
\hline & & & Quick Communication \\
\hline & & \multirow[t]{2}{*}{ Universal Institution Branding } & Company Recognition \\
\hline & & & Stakeholder Publicity \\
\hline \multirow[t]{8}{*}{4} & \multirow[t]{8}{*}{ Parents } & \multirow{2}{*}{$\begin{array}{l}\text { Easy Visual proofs through } \\
\text { electronic media }\end{array}$} & Interview Feedback \\
\hline & & & Ease of document access \\
\hline & & \multirow[t]{2}{*}{ Avoid Rush Hour } & Personal Login \\
\hline & & & Anytime/Anywhere Process \\
\hline & & \multirow[t]{2}{*}{ Schedule Matching } & $\begin{array}{l}\text { Parental Schedule } \\
\text { Management }\end{array}$ \\
\hline & & & Unaltered daily affairs \\
\hline & & \multirow[t]{2}{*}{ Enhanced Social Status } & Parental Boasting \\
\hline & & & Magnified Family Image \\
\hline \multirow[t]{8}{*}{5} & \multirow[t]{8}{*}{ Society } & \multirow{2}{*}{$\begin{array}{l}\text { Pollution Control and Better } \\
\text { Environment }\end{array}$} & Rush Hour Eradication \\
\hline & & & $\begin{array}{l}\text { Calm and Composed } \\
\text { Atmosphere }\end{array}$ \\
\hline & & Societal Digitization & Tech Savvy \\
\hline & & & Digital Citizens \\
\hline & & Better Stakeholder Image & $\begin{array}{l}\text { Societal Promotion for } \\
\text { Industry }\end{array}$ \\
\hline & & & Recruiter Value and Trust \\
\hline & & Civil Society and Technological & Digital Literacy \\
\hline & & Advancement & E-Citizens \\
\hline
\end{tabular}


Table 4 : Constraint factors of On-line Campus Placement Model and their critical constituent elements

\begin{tabular}{|c|c|c|c|}
\hline Sl. No. & Issue & Factors affecting & $\begin{array}{l}\text { Critical Constituent } \\
\text { Elements }\end{array}$ \\
\hline \multirow[t]{9}{*}{1} & \multirow{9}{*}{ Recruiters } & \multirow{2}{*}{ Lack of motivation } & Fear of Automated Jobs \\
\hline & & & Machine Work Reluctance \\
\hline & & \multirow[t]{2}{*}{ IT Environment Mismatch } & $\begin{array}{l}\text { Digital Infrastructure } \\
\text { difference }\end{array}$ \\
\hline & & & Configuration Challenge \\
\hline & & \multirow{2}{*}{$\begin{array}{l}\text { High Expenses, Overheads and } \\
\text { Costs }\end{array}$} & $\begin{array}{l}\text { Recruitment Software } \\
\text { Maintenance }\end{array}$ \\
\hline & & & Proprietary and Licensing \\
\hline & & Manual Supervision Challenges & $\begin{array}{l}\text { Absence of Official } \\
\text { Supervision }\end{array}$ \\
\hline & & Brand Misuse & Institutional Hype \\
\hline & & & Negative Imagery \\
\hline \multirow[t]{8}{*}{2} & \multirow[t]{8}{*}{ Students } & \multirow[t]{2}{*}{ Navigation Confusion } & Portal Complexity \\
\hline & & & $\begin{array}{c}\text { Comprehension \& Technical } \\
\text { Hurdles }\end{array}$ \\
\hline & & \multirow[t]{2}{*}{ Casual Take } & $\begin{array}{l}\text { Lack of Corporate } \\
\text { Environment }\end{array}$ \\
\hline & & & $\begin{array}{l}\text { Inherent Lethargy and } \\
\text { Laziness }\end{array}$ \\
\hline & & \multirow[t]{2}{*}{ Student Innocence and Ignorance } & Lack of digital practice \\
\hline & & & Online Knowledge Deficit \\
\hline & & \multirow[t]{2}{*}{ Negative Student Image } & Online Profile Rejection \\
\hline & & & Unsatisfactory Feedback \\
\hline \multirow[t]{8}{*}{3} & \multirow[t]{8}{*}{ Institutions } & \multirow[t]{2}{*}{ High Power Consumption } & Burden on Resources \\
\hline & & & Increased Overheads \\
\hline & & \multirow[t]{2}{*}{ Lack of company personnel } & State of Dilemma \\
\hline & & & Casual Take \\
\hline & & \multirow{2}{*}{ Timing mismatch with recruiter } & Conflict with Academics \\
\hline & & & Institute Operations \\
\hline & & \multirow[t]{2}{*}{ Negative college image } & Online Process Failure \\
\hline & & & Technical Incompetence \\
\hline \multirow[t]{8}{*}{4} & \multirow[t]{8}{*}{ Parents } & \multirow[t]{2}{*}{ Lack of interest and lethargy } & Family Detachment \\
\hline & & & Children Motivation \\
\hline & & \multirow[t]{2}{*}{ Emotional Stress } & Moral Counselling \\
\hline & & & Expectation Failure \\
\hline & & \multirow[t]{2}{*}{ Inferiority complex } & Interview Failure of Kids \\
\hline & & & Interview Success of others \\
\hline & & \multirow{2}{*}{$\begin{array}{l}\text { Unable to comprehend technical } \\
\text { aspects }\end{array}$} & Digital Illiteracy \\
\hline & & & Family Communication Issues \\
\hline \multirow[t]{8}{*}{5} & \multirow[t]{8}{*}{ Society } & \multirow[t]{2}{*}{ Procrastinated Society } & Digital Lethargy \\
\hline & & & Sedentary Lifestyle \\
\hline & & Burden on Resources & High Power Consumption \\
\hline & & & Overloaded Networks \\
\hline & & Digital Chaos & Increased Online Traffic \\
\hline & & & Online Congestion \\
\hline & & Cut-throat competition among & Social Status Contest \\
\hline & & families & Inter-Family Animosity \\
\hline
\end{tabular}


Table 5 : Disadvantageous factors of On-line Campus Placement Model and their critical constituent elements

\begin{tabular}{|c|c|c|c|}
\hline Sl. No. & Issue & Factors affecting & $\begin{array}{l}\text { Critical Constituent } \\
\text { Elements }\end{array}$ \\
\hline \multirow[t]{8}{*}{1} & \multirow[t]{8}{*}{ Recruiters } & \multirow[t]{2}{*}{ Rigid and Tedious } & Installation of Process \\
\hline & & & Implementation of Process \\
\hline & & \multirow[t]{2}{*}{ Poor IT Infrastructure Support } & $\begin{array}{l}\text { Institution Technical } \\
\text { Shortcomings }\end{array}$ \\
\hline & & & Staff Incompetency \\
\hline & & \multirow[t]{2}{*}{ Application and Portal Downtimes } & Technical Error \\
\hline & & & System Lags \\
\hline & & \multirow[t]{2}{*}{ Negative Imagery } & Process Failure \\
\hline & & & Lack of Campus Guidance \\
\hline \multirow[t]{8}{*}{2} & \multirow[t]{8}{*}{ Students } & \multirow[t]{2}{*}{ De-motivation } & Process Complexity \\
\hline & & & Family Burdens \\
\hline & & \multirow{2}{*}{$\begin{array}{l}\text { Student Absence and Access } \\
\text { Failure }\end{array}$} & Sick Offs and Bunking \\
\hline & & & Interview Reluctance \\
\hline & & \multirow{2}{*}{$\begin{array}{l}\text { Student Rigidity and } \\
\text { Procrastination }\end{array}$} & External Distractions \\
\hline & & & Comprehension Inability \\
\hline & & \multirow[t]{2}{*}{ Student Laziness and Lethargy } & Age Factors \\
\hline & & & Vague Career Clarity \\
\hline \multirow[t]{8}{*}{3} & \multirow[t]{8}{*}{ Institutions } & \multirow[t]{2}{*}{ Complications \& Complexities } & Installation Challenges \\
\hline & & & Implementation Limitations \\
\hline & & \multirow[t]{2}{*}{ Schedule conflicts with Recruiter } & Academic with Corporate \\
\hline & & & Academic Commitments \\
\hline & & \multirow[t]{2}{*}{ Restlessness and Disorder } & Failed Process \\
\hline & & & Execution Challenges \\
\hline & & \multirow[b]{2}{*}{ Negative Imagery } & Recruiter Risk \\
\hline & & & On-line Reputation \\
\hline \multirow[t]{8}{*}{4} & \multirow[t]{8}{*}{ Parents } & \multirow[b]{2}{*}{ Non-flexible Parental Schedule } & Busy Working Parents \\
\hline & & & $\begin{array}{l}\text { Conflicting Family } \\
\text { Schedules }\end{array}$ \\
\hline & & \multirow[b]{2}{*}{ Mental Distress and Suffering } & Children's Performance \\
\hline & & & Opinion Conflicts \\
\hline & & \multirow[t]{2}{*}{ Social Stigma } & Status Differences \\
\hline & & & Family Reputation Risk \\
\hline & & \multirow[t]{2}{*}{ Comprehension Inability } & Educational Background \\
\hline & & & Personal Disinterestedness \\
\hline \multirow[t]{8}{*}{5} & \multirow[t]{8}{*}{ Society } & \multirow{2}{*}{$\begin{array}{l}\text { Manual Job Loss and } \\
\text { Unemployment }\end{array}$} & Digital Invasion \\
\hline & & & Automation Fear \\
\hline & & Digital Over Crowding & Server Over Load \\
\hline & & & Network Congestion \\
\hline & & Deprived E-Convenience & Digital Discrimination \\
\hline & & & Connectivity Factors \\
\hline & & Creation of social inequalities & Status Competitions \\
\hline & & among families & Family Image Risk \\
\hline
\end{tabular}

\section{Conclusion}


We have studied determinant issues and affecting factors of online campus placement model using ABCD analysis framework. The analysis identified the affecting factors for various determinant issues under four constructs advantages, benefits, constraints, and disadvantages. The analysis has brought about 158 critical constituent elements which satisfy the success for its existence. Through this research, new insights were also generated about possibilities of building a robust online placement training model as well to cater and adhere the inevitable application of Online Industry Oriented Placement Model (OIOC) in nearing future. With digital India initiatives gathering momentum in the nation, employers are shifting towards OIOC adaptability and approach.

\section{References}

[1] Shenoy, Varun, \& Aithal, P. S., (2016). Green Placement - An Innovative Concept \& Strategy in Campus Placement Model IRA- International Journal of Technology \& Engineering, 4(3), 151-163. DOI : http://dx.doi.org/10.21013/jte.v4.n3.p3.

[2] Shenoy, Varun, \& Aithal, P. S., (2016). Changing Approaches in Campus Placements - A New Futuristic Model.International Journal of Scientific Research and Modern Education (IJSRME), 1 (1), pp. 766 - 776. DOI : http://doi.org/10.5281/zenodo.160966.

[3] Shenoy, Varun, (2015). MOOC: Recent Advancements in Personnel Trainings. International Journal of Management, IT and Engineering (IJMIE), 5(7), 39 - 44.

[4] Shenoy, Varun, (2016). Recent Trends in Branding for Ideal Placements. International Journal of Scientific Research and Modern Education (IJSRME), 1(1), 250 - 253.

[5] Kaplan, R., \& Norton, D., (1992), The Balanced Scorecard - Measures That Drive Performance. Harvard Business Review, Jan-Feb, 71-79.

[6] Lee S. F., and Ko, A. S. O., (2000). Building Balanced Scorecard with SWOT Analysis, and Implementing, Sun Tzu's The Art of Business Management Strategies' on QFD Methodology. Managerial Auditing Journal, 15 (1-2), 68-76.

[7] Porter, M.E. (2008). The Five Competitive Forces That Shape Strategy. Harvard Business Review, Available at: http://hbr.org/2008/01/the-five-competitive-forces-that-shape-strategy/

[8] Capps III, C. J., \&Glissmeyer, M. D. (2012).Extending the competitive profile matrix using internal factor evaluation and external factor evaluation matrix concepts. Journal of Applied Business Research, 28(5), 1059.

[9] Shahbandarzadeh, H., \& Haghighat, F. (2011). Evaluation of the strategies of target market selection on the basis of IFE and EFE matrixes using linmap technique (A case study of Bushehr province). Iranian Journal of Management Studies, 3(3), 41-56.

[10] Hambrick, D. C., MacMillan, I. C., \& Day, D. L. (1982). Strategic Attributes and Performance in the BCG Matrix-A PIMS-Based Analysis of Industrial Product Businesses1. Academy of Management Journal, 25(3), 510-531.

[11] Srdjevic, Z., Bajcetic, R., \& Srdjevic, B. (2012). Identifying the criteria set for multicriteria decision making based on SWOT/PESTLE analysis: A case study of reconstructing a water intake structure. Water resources management, 26(12), 3379-3393.

[12] Zalengera, C., Blanchard, R. E., Eames, P. C., Juma, A. M., Chitawo, M. L., \& Gondwe, K. T. (2014). Overview of the Malawi energy situation and A PESTLE analysis for sustainable development of renewable energy. Renewable and Sustainable Energy Reviews, 38, 335-347. 
[13] Aithal, P. S., Shailashree, V. T., Suresh Kumar, P. M. (2015). A New ABCD Technique to Analyze Business Models \& Concepts. International Journal of Management, IT and Engineering (IJMIE), 5(4), 409 - 423. DOI :http://doi.org/10.5281/zenodo.61652.

[14] Reshma, Aithal, P S, Shailashree, V T, Sridhar Acharya, P. (2015). An Empirical study on working from home - A popular E-business model. International Journal of Advance and Innovative Research, 2(2 (I)), 12-18. DOI : http://doi.org/10.5281/zenodo.164429.

[15] Aithal, P. S., Suresh Kumar, P. M., (2015). Black Ocean Strategy - A Probe into a new type of Strategy used for Organizational Success, GE International Journal of Management Research, 3(8), 45 65. DOI: http://doi.org/10.5281/zenodo.163423.

[16] Aithal, P. S., Shailashree, V. T., \& Suresh Kumar, P. M. (2015). Application of ABCD Analysis Model for Black Ocean Strategy, International Journal of Applied Research (IJAR), 1(10), 331-337. DOI:http://doi.org/10.5281/zenodo.163424.

[17] Aithal, P. S. \&Suresh Kumar, P. M. (2015). Enhancement of Graduate attributes in Higher Education Institutions through Stage Models. IMPACT: International Journal of Research in Business Management, Vol. 3, Issue 3, pp. 121 - 130. DOI : 10.5281/zenodo.61640.

[18] Aithal, P. S., Shailashree, V. T., \& Suresh Kumar, P. M. (2016). ABCD analysis of Stage Model in Higher Education.International Journal of Management, IT and Engineering (IJMIE), 6(1), 11-24. DOI: http://doi.org/10.5281/zenodo.154233.

[19] Aithal, P. S., Shailashree, V.T., \& Suresh Kumar, P. M. (2016). Analysis of NAAC Accreditation System using ABCD framework.International Journal of Management, IT and Engineering (IJMIE), 6(1), 30 - 44. DOI:http://doi.org/10.5281/zenodo.154272.

[20] Aithal, P. S. \& Suresh Kumar, P. M. (2016). Opportunities and Challenges for Private Universities in India, International Journal of Management, IT and Engineering (IJMIE), 6(1,), 88-113. DOI :http://doi.org/10.5281/zenodo.161157.

[21] Aithal, P. S., Shailashree, V. T., \& Suresh Kumar, P. M. (2016). Application of ABCD Analysis Framework on Private University System in India.International Journal of Management Sciences and Business Research (IJMSBR), 5(4), 159-170. DOI :http://doi.org/10.5281/zenodo.161111.

[22] Aithal, P. S., Shailashree, V. T., \& Suresh Kumar, P. M., (2016). The Study of New National Institutional Ranking System using ABCD Framework. International Journal of Current Research and Modern Education (IJCRME), 1(1), 389 - 402. DOI :http://doi.org/10.5281/zenodo.161077.

[23] Aithal, P. S., Shailashree, V. T. \& Suresh Kumar, P. M., (2016). Analysis of ABC Model of Annual Research Productivity using ABCD Framework. International Journal of Current Research and Modern Education (IJCRME), 1(1), 846-858. DOI :http://doi.org/10.5281/zenodo.62022.

[24] Aithal, P. S., \& Suresh Kumar, P. M. (2016). ABC Model of Research Productivity and Higher Educational Institutional Ranking, Proceedings of National conference on Curriculum Design and Development for Student centric Learning, Mangalore, India, pp. 11-22. ISBN 978-81-929306-9-5.

[25] Shubhrajyotsna Aithal, \& Aithal, P. S., (2016), ABCD analysis of Dye doped Polymers for Photonic Applications, IRA-International Journal of Applied Sciences, 4(3), 358-378. DOI :http://dx.doi.org/10.21013/jas.v4.n3.p1.

[26] Reshma, Aithal, P. S. \& Sridhar Acharya, P. (2015). Relevance of On-line Office Administration through Working from Home in Future Education System. International Journal of Application or Innovation in Engineering \& Management, 4(4), 44-53. DOI :http://doi.org/10.5281/zenodo.163882. 
[27] Padmanabha Shenoy, \& Aithal P. S., (2016). A Study on History of Paper and possible Paper Free World. International Journal of Management, IT and Engineering (IJMIE), 6(1), 337-355. DOI :http://doi.org/10.5281/zenodo.161141.

[28] Aithal, P. S., (2015). Comparative Study on MBA Programmes in Private \& Public Universities - A case study of MBA programme plan of Srinivas University. International Journal of Management Sciences and Business Research (IJMSBR), 4(12), 106-122. DOI : http://doi.org/10.5281/zenodo.163884.

[29] Aithal, P. S., and Suresh Kumar P. M., (2016). Analysis of Choice Based Credit System in Higher Education. International Journal of Engineering Research and Modern Education (IJERME), 1(1), 278284. DOI :http://doi.org/10.5281/zenodo.161046.

[30] Aithal, P. S. \& Shubhrajyotsna Aithal, (2016). A New Model for Commercialization of Nanotechnology Products and Services. International Journal of Computational Research and Development, 1(1), 84-93. DOI :http://doi.org/10.5281/zenodo.163536.

[31] Shubrajyotsna Aithal \& Aithal, P. S., (2016). Student Centric Learning through Planned Hard work An Innovative Model. International Journal of Scientific Research and Modern Education (IJSRME), 1(1), 886-898. DOI: http://doi.org/10.5281/zenodo.61830.

[32] Rogers, E. M., (1995). Diffusion of Innovation. The Free Press, NY.

[33] Aithal, P. S. and Varambally, K. V. M. (2006). Security Issues in Online Financial Transactions with Special Reference to Banking Industry. In Quality in Service Sector and Managerial Challenges - Allied Publisher Pvt. Ltd. 2006, ISBN: 81-7764-992-2, pp 103- 114.

[34] Varambally, K. V. M., \& Aithal, P. S. (2009). Technological Management and Mobile Business Services in India - A Futuristic Approach, Proceedings on MIDISA - SAARC Conference on Change and Continuity : Management Prospects and Challenges, RIM, Thimphu, Bhutan, 121-139.

[35] Aithal, P. S., \& Varambally, K. V. M. (2009). Mobile Business Technology and Business Proliferation of Banks - A futuristic Approach.Amity Business Review - an Indian Journal, 10(1), 9-25.

[36] Aithal. P. S., \& Shubhrajyotsna Aithal, (2015). A review on Anticipated Breakthrough Technologies of 21st Century. International Journal of Research \& Development in Technology and Management Sciences, 21(6), 112-133. DOI : http://doi.org/10.5281/zenodo.61617.

[37] Aithal, P. S., \& Shubhrajyotsna Aithal, (2015). An Innovative Education Model to realize Ideal Education System. International Journal of Scientific Research and Management (IJSRM), 3(3), 2464 2469. DOI: http://doi.org/10.5281/zenodo.61654. 